\title{
The Analysis of Deng Xiaoping's Peripheral Diplomatic Thoughts
}

\author{
Pei PENG \\ School of Marxism \\ Jianghan University \\ Wuhan, China
}

\begin{abstract}
Deng Xiaoping's peripheral diplomatic thoughts were formed under the background of major changes in the international and domestic situation. It is based on safeguarding national interests, and advocates transcending differences in ideology and social system on the basis of the Five Principles of Peaceful Co-existence and independence. Its implementation extremely improves the relationship between China and her neighboring countries; it also laid solid foundations for China's current foreign policy on neighboring countries.
\end{abstract}

Keywords-Deng Xiaoping; peripheral diplomatic thoughts; the Five Principles of Peaceful Co-existence

\section{INTRODUCTION}

The peripheral diplomacy has always played an important role in China's diplomatic strategy. In the late 1970s and early 1980 s, in accordance with the new changes in the international situation and the need to concentrate on economic construction at home, Deng Xiaoping advocated developing friendly relations with all neighboring countries transcending differences in ideology and social system on the basis of the Five Principles of Peaceful Co-existence and independence. Under the guidance of Deng Xiaoping's peripheral diplomacy, China has greatly improved its relations with neighboring countries. The implementation of Deng Xiaoping's peripheral diplomacy created a favorable environment for China's socialist modernization, promoted the stability and prosperity of the Asia-pacific region, and made positive contributions to world peace and development. It also laid a solid foundation for China's current foreign policy on neighboring countries.

\section{THE BACKGROUND OF THE FORMATION OF DENG XiAOPING'S PERIPHERAL DIPLOMATIC THOUGHTS}

Managing relations with neighboring countries has always been an important part of China's diplomacy. In the 1950s, Premier Zhou Enlai put forward the principle of "stabilizing the neighbors", which has been throughout the diplomatic process of New China. However, before the Third Plenary Session of the Eleventh Central Committee of the Communist Party of China, China's peripheral diplomacy was always seriously affected and restricted by the Cold War. Under the circumstances of confrontation between the United States and the Soviet Union, the peripheral diplomatic thoughts of the first generation of leaders represented by Mao Zedong embodied the characteristics of revolution and struggle. Therefore, while making many achievements, the healthy development of China's relations with some neighboring countries is greatly hindered.

In the late 1970s and early 1980s, great changes took place in both the international and domestic situations.

First of all, peace and development are the themes of the world. On the one hand, the situation of struggle for hegemony between the United States and the Soviet Union had changed. Although the basic characteristics of the international pattern still showed that the two superpowers of the United States and the Soviet Union continue to seek hegemony in the world, the strategic situation of mutual attack and defense had emerged due to the change of the strength of the two sides. On the other hand, other forces on the international stage, such as Japan, Western Europe and the Third World, were also rising rapidly and playing an increasingly prominent role. Therefore, the confrontational situation caused by the US-Soviet struggle had changed into a situation of both confrontation and dialogue because of the struggle of international peace forces. Peace and development has become universal aspirations and urgent demands of the peoples of the world. The threat of war is decreasing and the power of peace is expanding. It was precisely according to the new characteristics of the international situation that Deng Xiaoping held that the growth of world peace factors exceeds that of war factors. On the basis of this judgment, China formulated a policy centered on economic development. In the middle of 1980s, Deng Xiaoping clearly put forward the theme of "peace and development". The process of Deng Xiaoping's judgment on the theme of The Times is also the process of the gradual formation and perfection of Deng Xiaoping's peripheral diplomatic thoughts.

Secondly, the focus of China's national work shifted from class struggle to economic construction. While the international situation changed, China's domestic situation had also undergone tremendous changes. At the Third Plenary Session of the Eleventh Central Committee of the Communist Party of China in 1978, the second generation of leading collectives with Deng Xiaoping as the core abandoned the wrong policy of "class struggle" and shifted the work center of the Party and the state to economic construction. In March 1979, Deng Xiaoping pointed out, "our productivity is far from being able to meet the needs of the people and the country. This is the principal contradiction of our time, and the central task is to resolve it." Therefore, "we should quickly and resolutely shift the focus of our work to economic 
construction." [1] Marked by the Third Plenary Session of the Eleventh Central Committee of the Communist Party of China, China entered a new era of focusing on economic construction. The national development strategy centered on economic construction must depend on a stable international environment, especially a stable surrounding environment.

\section{The MAIN CONTENTS OF DENG XIAOPING'S PERIPHERAL DIPLOMATIC THOUGHTS}

Deng Xiaoping's peripheral diplomatic thoughts were formed under the background of major changes in the international and domestic situation. It is based on safeguarding national interests, advocates developing friendly relations with all neighboring countries transcending differences in ideology and social system on the basis of the Five Principles of Peaceful Co-existence and independence. It mainly includes the following aspects.

Firstly, transcend ideological and social differences and take national interests as the basic purpose to develop relations with neighboring countries.

The national interest is the basis for determining national diplomatic objectives. The fundamental purpose of foreign strategy is to pursue and defend national interests. Among the leaders of New China, Deng Xiaoping was the first to put forward the idea of taking national interests as the starting point of China's diplomacy. Deng Xiaoping believes that it is the national interest rather than ideology that determines the relationship between countries, and national interest is the starting point of foreign relations and the basis for formulating foreign policies. Safeguarding national interests is the most important task of foreign work. Deng Xiaoping stressed many times, "Considering the relations between countries, we should proceed mainly from the strategic interests of the country itself, focus on your own long-term strategic interests and respect each other's interests without caring about the historical enmity, social system and ideological differences". "We all talk about problems and deal with them on the basis of the national interests".[2] Beyond the differences of ideology and social system, taking national interests as the highest criterion of China's foreign relationship reflects the fundamental change of China's diplomatic thought. The basic purpose of Deng Xiaoping's Peripheral Diplomacy is to maintain and realize the fundamental interests of the country. It opened a new era of China's peripheral diplomacy, China's Peripheral Diplomacy changed from the original "revolutionary diplomacy" to the realistic diplomacy to realize "maximization of national interests".

Secondly, develop friendly relationship with all neighboring countries on the basis of the Five Principles of Peaceful Co-existence and independence. Independence is the basic principle and position that has been consistently adhered to in the new China's foreign policy. In the new historical period, Deng Xiaoping once again solemnly pointed out, "independence and self-reliance is our foothold regardless of the past, present and future." The Five Principles of Peaceful Co-existence have been the basic norms of China's handling of international relationship since it was put forward in 1954. Deng Xiaoping also adhered to it when dealing with neighboring countries. In 1982, the Five Principles of Peaceful Co-existence were explicitly included in the preamble of China's new constitution.

On the basis of upholding the Five Principles of Peaceful Co-existence, China developed friendly relationship with its neighbors in all aspects. While focusing on improving and stabilizing relationship with the big neighboring countries such as the Soviet Union (Russia), Japan and India, China also adheres to the principle of good-neighborly friendship and equality with other neighboring countries. And China took active measures to improve relationship with Vietnam, Laos, Mongolia, Indonesia and other countries.

Thirdly, resolve territorial disputes by "putting aside disputes for joint development" and promote friendly cooperation between China and neighboring countries.

Because of historical reasons, China has territorial sovereignty disputes with some neighboring countries. Territorial conflicts have long plagued relationship between China and its neighbors. In order to resolve territorial disputes with these neighboring countries, Deng Xiaoping creatively put forward a new idea of solving international disputes -"putting aside disputes for joint development".'Putting aside disputes and jointly developing" means temporarily releasing those disputed sovereignty issues, avoiding intensification of contradictions between the two sides, starting with economic interests, linking the parties in disputes with the common ties of economic interests, creating a harmonious and favorable atmosphere for the rational settlement of disputes, and ultimately eliminating disputes. This idea of turning disputes and potential conflicts into cooperation is in line with the strategic interests of the parties concerned. It has been responded by the relevant countries, reducing their hostility towards China, and is conducive to the proper settlement of the dispute. The idea of "putting aside disputes for joint development" is Deng Xiaoping's great contribution to the theory of international relationship and has greatly promoted the friendly cooperation between China and its neighboring countries.

\section{The SignificAnce of Deng XiaOPING's PERIPHERAL DIPLOMATIC THOUGHTS.}

Deng Xiaoping's peripheral diplomatic thoughts is not only the inheritance and development of Mao Zedong's thought of good-neighborly diplomacy, but also the product of the combination of Marxism and China's national conditions. Under the guidance of Deng Xiaoping's peripheral diplomacy thought, China's peripheral diplomacy made remarkable achievements.

First of all, the implementation of Deng Xiaoping's peripheral diplomatic thoughts greatly improved China's relationship with neighboring countries and created a favorable environment for China's socialist modernization.

The normalization of Sino-Soviet relations is the most important achievement of China's Peripheral Diplomacy in the 1980s under the direct guidance of Deng Xiaoping's peripheral diplomatic thoughts. After the collapse of the Soviet Union, the transformation from Sino-Soviet relations to Sino-Russian 
relations was successfully realized. At the same time, the relationship between China-Japan made great progress. China's traditional friendly relationship with North Korea, Southeast Asia and South Asian countries had been further maintained. The Sino-Indian and Sino-Vietnamese relationship which were once hostile were also improved during this period. The relationship between China and Mongolia improved too. By the end of the 1980s, China had no openly hostile country in the surrounding region. The friendly relationship between China and its neighboring countries created a favorable environment for China's socialist modernization.

Secondly, the implementation of Deng Xiaoping's peripheral diplomatic thoughts not only effectively promoted the stability and prosperity of the Asia-pacific region, but also made positive contributions to world peace and development.

China is a major power in the Asia-pacific region. The relationship between China and its neighboring countries directly affects the stability and prosperity of the Asia- Pacific region. Deng Xiaoping's peripheral diplomatic thoughts emphasize peaceful co-existence and good neighborliness between neighboring countries. The implementation of Deng Xiaoping's peripheral diplomatic thoughts not only won a good surrounding environment for China, but also promoted the stability and prosperity of the Asia-pacific region. Deng Xiaoping's" putting aside disputes for joint development "provides a new way of thinking, new method and new way to solve international disputes. It not only enriches the theory of contemporary international relationship, but also has reference significance to how countries get along with each other.

Finally, the implementation of Deng Xiaoping's peripheral diplomatic thoughts has laid a solid foundation for China's current neighborhood diplomacy philosophy of "amity, sincerity, mutual benefit and inclusiveness", as well as the implementation of the "Community with a Shared Future for Neighboring Countries " and the "One Belt And One Road" initiative.

In October 2013, President Xi Jinping put forward the concept of "amity, sincerity, mutual benefit and inclusiveness" in his neighborhood diplomacy. Xi Jinping proposed actively building regional economic integration with neighboring countries, strengthening regional security cooperation, developing public diplomacy and non-governmental diplomacy. Xi Jinping put forward the strategic goal of connecting the Chinese dream with the regional dream and the Asian dream to build the "Community with a Shared Future for Neighboring Countries ". In the specific diplomatic practice, China actively develops Silk Road diplomacy, and puts forward the "One Belt And One Road" initiative based on "consultation, contribution and shared benefits ". China emphasizes that the fruits of China's economic development should benefit its neighboring countries, and that China and its neighboring countries should follow the path of interconnection, common development and common prosperity.[3] Deng Xiaoping's peripheral diplomatic thoughts have laid a solid foundation for these creative new ideas, policies and initiatives. Because the essence of the two is the same, that is, both advocate the development of goodneighborly and friendly relationship with neighboring countries and carry out mutually beneficial cooperation in various fields. The implementation of China's long-term foreign policy of good-neighborliness has laid a realistic foundation for China to further strengthen its friendly and cooperative relationship with its neighboring countries.

\section{SUMmary}

Deng Xiaoping's peripheral diplomatic thoughts were formed under the background of major changes in the international and domestic situation. It mainly includes three aspects. (1) transcend ideological and social differences and take national interests as the basic purpose to develop relations with neighboring countries. (2) develop friendly relationship with all neighboring countries on the basis of the Five Principles of Peaceful Co-existence and independence. (3)resolve territorial disputes by "putting aside disputes for joint development" and promote friendly cooperation between China and neighboring countries. The implementation of Deng Xiaoping's peripheral diplomacy created a favorable environment for China's socialist modernization, promoted the stability and prosperity of the Asia-pacific region, and made positive contributions to world peace and development. It also laid a solid foundation for China's current neighborhood diplomacy philosophy of "amity, sincerity, mutual benefit and inclusiveness", as well as the implementation of the "Community with a Shared Future for Neighboring Countries " and the "One Belt And One Road" initiative.

\section{REFERENCES}

[1] Deng Xiaoping, Selected works of Deng Xiaoping: Volume 3. Beijing: People's Publishing House, 1993, pp10-11. (In Chinese)

[2] Deng Xiaoping, Selected works of Deng Xiaoping: Volume 3. Beijing: People's Publishing House, 1993, pp330. (In Chinese)

[3] Sun Bai-hong, "On Innovations of Xi Jinping Thought on Neighboring Dip lo macy”, Journal of Weinan Normal University, vol.32(18), pp11-17; Sept.2017.(In Chinese) 